\title{
PENGELOLAAN ARSIP DINAMIS DI KANTOR BADAN PERTANAHAN NASIONAL (BPN) KABUPATEN KLATEN
}

\author{
Pasha Pradipta Putri, Purwanto, Wahyu Rusdiyanto \\ Pendidikan Administrasi Perkantoran, Fakultas Ekonomi, Universitas Negeri Yogyakarta, Indonesia \\ pasha.pradipta2015@student.uny.ac.id, purwanto@uny.ac.id, wahyu_rusdiyanto@uny.ac.id
}

\begin{abstract}
Abstrak: Pengelolaan Arsip Dinamis di Kantor Badan Pertanahan Nasional (BPN) Kabupaten Klaten. Penelitian ini bertujuan untuk mengetahui pengelolaan arsip dinamis di Kantor Badan Pertanahan Nasional (BPN) Kabupaten Klaten. Penelitian ini menggunakan metode deskriptif dengan pendekatan kualitatif. Informan kunci (key informant) penelitian yaitu Kepala Subbagian Tata Usaha. Informan pendukung terdiri dari satu pegawai Subbagian Tata Usaha dan tiga pegawai kearsipan. Pengumpulan data menggunakan teknik observasi, wawancara, dan dokumentasi. Teknik analisis data dimulai dari pengumpulan data, reduksi data, penyajian data, dan diakhiri dengan penarikan kesimpulan. Keabsahan data ditentukan menggunakan teknik triangulasi sumber dan metode. Hasil penelitian ini menunjukkan bahwa pengelolaan arsip dinamis meliputi, pengelolaan surat masuk dan surat keluar. Sistem penyimpanan arsip menggunakan sistem wilayah, nomor, dan tanggal. Asas penyimpanan arsip menggunakan asas kombinasi antara sentralisasi dan desentralisasi. Peminjaman dan penemuan kembali arsip dilakukan ketika ada pegawai yang hendak meminjam arsip. Pemeliharaan arsip belum dilakukan dengan baik.
\end{abstract}

Kata kunci: Pengelolaan, Arsip Dinamis, BPN Kabupaten Klaten

\begin{abstract}
The Management Of Dynamic Archives In The Office Of National Land Agency (NLA) Klaten Regency. This research aims to know the management of dynamic archives in the Office of National Land Agency (NLA) Klaten. This research belonged to descriptive research by applying qualitative approach. Key informant of this research is the Head of Sub Administrative Division. Supporting informants of this research are an employee of sub administrative division and three employee of management records. The techniques of data collection of this research were observation, interview, and documentation. The data were analyzed by using data collection, data reduction, data presentation, and drawing a conclusion. The reliability of the data of this research were resource triangulation and method triangulation. The findings reveal that: the management of dynamic archives include, the management of inbox and outbox. The system of archives storage uses a geographical system, a numerical, and a chronological. The principle of archives storage uses a combination between centralization and decentralization. The borrowing and refinding system are carried out when there is an employee who will borrow the archives. The maintenance of the archives are not good enough.
\end{abstract}

Keyword: Management, Dynamic Archives, NLA Klaten

\section{PENDAHULUAN}

Perkembangan ilmu pengetahuan dan teknologi mempunyai dampak yang besar dalam kegiatan perkantoran. Bertambhnya kegiatan perkantoran berdampak pada jumlah informasi yang diolah, dibutuhkan dan dihasilkan. Informasi diperlukan sebagai bahan pertimbangan 
dalam pemecahan masalah, pembuatan keputusan maupun penentuan tujuan organisasi. Setiap kantor dituntut untuk dapat memberikan suatu informasi secara tepat, cepat dan akurat. Informasi dodapatkan dari berbagai media. Salah satu sumber informasi yang dapat digunakan adalah dokumen baru maupun lama yang sudah menjadi arsip. The Liang Gie (2009: 118) mendefinisikan arsip sebagai "kumpulan warkat yang disimpan secara sistematis karena mempunyai suatu kegunaan agar setiap kali diperlukan cepat diketemukan kembali”. Arsip memiliki peran penting dalam proses penyajian informasi bagi pimpinan sebagai bahan pemecahan masalah, pertimbangan dalam pengambilan keputusan dan perumusan kebijakan.

Instansi pemerintah pada umumnya mempunyai fungsi sebagai penyedia layanan bagi masyarakat umum. Kelancaran dan keberhasilan pelayanan tersebut tidak terlepas dari keberhasilan dalam pengelolaan arsip yang baik dan benar. Pegawai sebagai pelaksana kearsipan secara langsung akan menentukan baik buruknya kegiatan pengelolaan arsip. Menurut Kurniatun (2011: 142) dalam jurnalnya mengungkapkan bahwa "Pengelolaan arsip secara baik yang akan menunjang kegiatan administrasi agar lebih lancar". Semua pegawai diharapkan menyadari betapa pentingnya arsip dalam pelaksanaan kerja, terutama di instansi pemerintah yang mempunyai kegiatan pelayanan menuntut kesadaran para pegawai terhadap pentingnya pengelolaan arsip.

Pengelolaan arsip secara tepat oleh suatu oraganisasi berpengaruh positif terhadap tingkat kemudahan dalam penemuan kembali suatu arsip. Penemuan kembali arsip menurut Ig. Wursanto (2007: 187) adalah "kegiatan memastikan dimana warkat atau arsip yang akan dipergunakan disimpan dalam kelompok berkas apa disusun menurut sistem apa dan bagaimana cara mengambilnya”. Fasilitas yang digunakan dalam pengelolaan arsip juga merupakan kebutuhan yang harus diperhatikan oleh suatu organisasi. Fasilitas penyimpanan arsip, fasilitas pemeliharaan dan perawatan arsip yang digunakan harus diperhatikan agar tetap layak untuk menjamin keamanan data dan informasi yang ada didalamnya. Beberapa hasil penelitian juga menyebutkan suasana dan lingkungan kerja yang mendukung pengelolaan arsip berpengaruh positif bagi kinerja pegawai maupun keberhasilan pengelolaan arsip.

Indonesia mengatur pengelolaan arsip dalam Undang-Undang Nomor 7 Tahun 1971 tentang Ketentuan-Ketentuan Pokok Kearsipan. Undang-undang tersebut diperbaharui menjadi Undang-Undang Nomor 43 Tahun 2009 tentang kearsipan. Pembaharuan peraturan mengenai pengelolaan arsip dilakukan dengan tujuan agar pengelolaan arsip dapat dilakukan dengan baik dan benar sehingga tujuan organisasi dapat tercapai. Berdasarkan peraturan yang telah dibuat pemerintah, seyogyanya organasisasi harus tertib dalam mengelola arsip. 
Perlu disadari bahwa mengelola arsip bukanlah suatu hal yang mudah, tetapi memerlukan suatu penanganan yang serius. Penyimpanan arsip perlu memperhatikan pemilihan sistem kearsipan yang akan digunakan sehingga dapat efisiensi kerja dalam bidang kearsipan dapat tercapai. The Liang Gie (2009: 120) membagi sistem penyimpanan arsip berdasarkan abjad, pokok soal, wilayah, nomor, dan tanggal.

Pada zaman globalisasi seperti sekatang ini, masih terdapat beberapa organisasi (pemerintah maupun swasta) yang mengelola arsip dengan tidak baik dan tidak profesional. Pengelolaan arsip dalam suatu organisasi terkadang masih dipandang sebagai pekerjaan yang tidak penting, mereka beranggapan bahwa pengelolaan arsip adalah suatu pekerjaan yang mudah, sehingga banyak suatu organisasi atau perusahaan yang menyerahkan urusan kearsipan kepada orang yang tidak memiliki latar belakang pendidikan tentang kearsipan. Padahal ketidakberhasilan dalam pengelolaan arsip akan menjadi hambatan besar proses pencarian informasi yang menjadi dasar dalam pengambilan keputusan.

Kantor Badan Pertanahan Nasional (BPN) Kabupaten Klaten adalah salah satu lembaga Pemerintah non Kementerian Indonesia yang bertugas melaksanakan tugas Pemerintah di bidang Pertanahan sesuai dengan ketentuan peraturan perundang-undangan. Peran lain kantor BPN meliputi: (a) melaksanakan penyusunan dan penetapan kebijakan di bidang pertanahan, (b) perumusan dan pelaksanaan kebijakan di bidang survei, pengukuran, pemetaan, (c) penetapan hak tanah, pendaftaran tanah, pemberdayaan masyarakat, (d) pengaturan, penataan, pengendalian kebijakan pertanahan, (e) pengadaan tanah, (f) pengendalian dan penanganan sengketa dan perkara pertanahan, (g) pengawasan atas pelaksanaan tugas, (h) koordinasi tugas, pembinaan, pemberian dukungan administrasi kepada seluruh unit organisasi, (i) pengelolaan data informasi lahan pertanian dan pertanahan, (j) penelitian dan pengembangan, serta $(\mathrm{k})$ pengembangan sumber daya manusia. Kantor BPN Kabupaten Klaten dibagi menjadi enam bidang, yaitu Bidang Tata Usaha, Infrastruktur Pertanahan, Hubungan Hukum Pertanahan, Penataan Pertanahan, Pengadaan Tanah, serta Penanganan Masalah dan Pengendalian Pertanahan.

Berdasarkan hasil observasi yang dilakukan dengan melihat langsung Kantor BPN Kabupaten Klaten pada tanggal 27 Desember 2018, peneliti mendapatkan informasi bahwa dalam pelaksanaan pengelolaan arsip dinamis di kantor tersebut masih belum sepenuhnya baik dan tertib. Kondisi tersebut disebabkan oleh berbagai macam faktor. Faktor-faktor tersebut antara lain Kantor BPN Kabupaten Klaten belum memiliki pegawai yang bertugas secara khusus sebagai arsiparis. Pengelolaan arsip hanya dilakukan oleh pegawai administrasi umum dan belum pernah mendapatkan pendidikan dan pelatihan tentang kearsipan, sehingga 
kurang memahami pengelolaan arsip yang baik. Menurut Sutirman (2010: 14) menjelaskan mengenai syarat petugas arsip bahwa "Petugas kearsipan dituntut untuk memiliki keterampilan dan prosedur yang benar dalam pengelolaan arsip, termasuk pada era Revolusi Industri 4.0 sekarang ini”.

Rendahnya perhatian dan kesadaran pegawai terhadap pentingnya pemeliharaan arsip, dapat dilihat dari kurangnya kesadaran pengelolaan arsip dari pegawai sehingga semakin hari arsip semakin menumpuk. Penataan arsip masih belum tertata dengan baik, terlihat dari banyaknya arsip dinamis yang kurang tertata dengan baik dan rapi, bahkan ada beberapa arsip yang ditumpuk sembarangan di lantai. Kondisi tersebut tentu saja dapat meningkatkan resiko kerusakan arsip. Selain itu, kondisi tersebut juga akan mengakibatkban kesulitan dalam penemuan kembali arsip. Fasilitas penyimpanan seperti rak lemari arsip terlihat berdebu dan kurang terawat. Map untuk menyimpan arsip kondisinya terlihat kurang baik sehingga arsip di dalamnya menjadi cepat kotor dan relatif mudah rusak. Dampak negatif dari penataan dan pemeliharaan arsip yang belum dilakukan dengan baik adalah penemuan kembali arsip yang membutuhkan waktu tidak sebentar. Saat dilakukan observasi, pegawai berhasil menemukan arsip yang kami minta dengan waktu 2-5 menit. Menurut The Liang Gie, standar penemuan kembali arsip dikatakan baik apabila proses penemuannya berjalan maksimal 1 menit.

Permasalahan lain yang ditemukan adalah ruang penyimpanan arsip yang belum memenuhi standar. Belum terpenuhinya standar pada ruang penyimpanan arsip terlihat dari ruangan tempat menyimpan arsip yang relative sempit sehingga tidak dapat menampung semua arsip yang ada. Fasilitas pemeliharaan dan perawatan arsip di kantor BPN Klaten juga tidak lengkap, seperti belum tersedianya alat pengukur suhu, alat pengukur temperatur dan kelembaban udara (thermohigrometer). Salah satu alat yang digunakan untuk menjaga kelembaban udara dan suhu udara agar tetap stabil adalah Air Conditioner (AC), pada kantor tersebut terdapat tiga ruang penyimpanan arsip namun hanya dua ruang penyimpanan arsip yang menggunakan AC, sedangkan satu ruang penyimpanan arsip yang lain belum menggunakan AC.

Berdasarkan pemaparan permasalahan yang ada di Kantor BPN Kabupaten Klaten dan menyadari betapa pentingnya peranan arsip tersebut maka dirasa perlu untuk melakukan penelitian tentang "Pengelolaan Arsip Dinamis di Kantor Badan Pertanahan Nasional (BPN) Kabupaten Klaten".

Berdasarkan latar belakang masalah yang telah dikemukakan tersebut dapat diindentifikasi beberapa masalah sebagai berikut: pelaksanaan pengelolaan arsip dinamis belum maksimal terlihat dari kecepatan penemuan kembali arsip rata-rata di atas dua menit, 
belum adanya tenaga arsiparis, pegawai pengelola arsip belum mendapatkan pendidikan dan pelatihan tentang kearsipan, rendahnya perhatian pegawai mengenai pentingnya pemeliharaan arsip, penataan arsip yang masih belum tertata dengan baik, fasilitas pengelolaan arsip yang belum memadai, dan ruang penyimpanan arsip belum memadai karena ruangan berukuran sempit. Mengingat keterbatasan waktu, biaya, dan tenaga, maka fokus penelitian ini dibatasi pada pengelolaan arsip dinamis di Kantor Badan Pertanahan Nasional (BPN) Kabupaten Klaten yang belum maksimal.

\section{METODE}

Penelitian ini menggunakan peniltian deskritif dengan pendekatan kualitatif. Penelitian ini menggambarkan keadaan subjek atau objek penelitian berdasarkan fakta-fakta yang tampak dan apa adanya. Data dan informasi yang diperoleh dideskripsikan sesuai dengan kenyataan yang ditemukan di lapangan dan disajikan dalam bentuk kata-kata atau kalimat yang kemudian ditarik menjadi sebuah kesimpulan. Penelitian ini dilaksanakan di Kantor Badan Pertanahan Nasional (BPN) Kabupaten Klaten yang beralamat di Jalan Veteran Nomor 88, Barenglor, Klaten Utara, Klaten, Jawa Tengah. Waktu penelitian dilaksanakan pada bulan September sampai dengan bulan Oktober 2019. Pemilihan informan dalam penelitian ini menggunakan teknik purposive sampling. Peneliti memilih informan penelitian berdasarkan kriteria dan pertimbangan tertentu. Dalam penelitian ini, informan yang dipilih adalah pegawai yang pekerjaannya berkaitan langsung dengan pengelolaan arsip dinamis di Kantor BPN Klaten sehingga diharapkan dapat memberikan data dan informasi yang tepat dan komprehensif. Informan dalam penelitian ini terdiri dari satu informan kunci yaitu Kepala Subbagian Tata Usaha. Informan pendukung dalam penelitain ini yaitu satu pegawai Subbagian Tata Usaha dan tiga orang pegawai kearsipan yang tugas pokok dan fungsinya secara langsung melaksanakan kegiatan kearsipan pada masing-masing gudang penyimpanan arsip.

Teknik pengumpulan data menggunakan observasi, wawancara, dan dokumentasi. Instrumen penelitian yang digunakan berupa pedoman observasi, pedoman wawancara, dan pedoman dokumentasi. Teknik analisis data yang digunakan dalam penelitian ini adalah analisis deskriptif. Teknik analisis data ini dilakukan melalui tiga tahap yaitu (1) reduksi data, (2) penyajian data, dan (3) penarikan kesimpulan. Proses ini berlangsung terus-menerus pada setiap tahapan penelitian, bahkan sebelum data benar-benar terkumpul.

Keabsahan data perlu dilakukan agar data yang diperoleh dapat dipertanggungjawabkan. Teknik keabsahan untuk menguji kredibilitas data yang digunakan 
dalam penelitian ini yaitu dengan menggunakan teknik triangulasi, baik triangulasi sumber maupun triangulasi metode. Teknik triangulasi sumber adalah untuk menguji kredibilitas data yang dilakukan dengan cara membandingkan data yang diperoleh dari hasil wawancara antara informan yang satu dengan informan penelitian yang lain. Teknik triangulasi metode digunakan untuk menguji kredibilitas data dan informasi. Ametode triangulasi dilakukan dengan cara membandingkan data yang diperoleh dari metode wawancara, observasi, dan dokumentasi. Langkah-langkah tersebut dilakukan agar data dan informasi yang diperoleh bersifat valid dan dapat diakui kebenarannya.

\section{HASIL PENELITIAN DAN PEMBAHASAN}

Berdasarkan perolehan data dan informasi dari hasil observasi, wawancara, dan dokumentasi yang telah dilakukan peneliti secara langsung di Kantor Badan Pertanahan Nasional (BPN) Kabupaten Klaten, maka pembahasan hasil penelitian adalah sebagai berikut:

\section{Pengelolaan Arsip Dinamis}

Pengelolaan arsip dinamis dalam suatu organisasi merupakan kegiatan penting yang harus mendapatkan perhatian karena dapat memperlancar pekerjaan dan memberikan informasi sebagai dasar pemecahan masalah dan pengambilan keputusan. Pengelolaan arsip dinamis di kantor BPN Klaten meliputi pengelolaan surat masuk dan surat keluar.

1. Pengelolaan Surat Masuk

Hasil penelitian yang telah dilakukan di Kantor Badan Pertanahan Nasional (BPN) Kabupaten Klaten bahwa pengelolaan surat masuk yaitu surat masuk diterima di Bagian Tata Usaha untuk dilakukan pengendalian surat dengan mencatat pada buku agenda surat masuk dan buku kepala kantor, kemudian surat disampaikan ke Kepala Kantor untuk pengecekan. Setelah itu surat didisposisi pada lembar disposisi surat. Kemudian surat tersebut diserahkan kembali ke Bagian Tata Usaha untuk didistribusikan kepada Seksi yang dituju supaya dapat diproses dan ditindaklanjuti sesuai dengan tujuan surat disertai dengan bukti penerimaan atau pengantar surat menggunakan buku ekspedisi. Pengelolaan surat masuk tersebut sesuai dengan pernyataan Ida Nuraida (2012: 76) bahwa surat masuk adalah surat yang masuk ke dalam suatu instansi/perusahaan atau bagian dalam suatu instansi/perusahaan, baik yang berasal dari instansi/perusahaan lain atau dari bagian lain pada instansi/perusahaan yang sama. Pengelolaan surat masuk mutlak dilakukan dengan baik supaya tidak terdapat surat yang hilang atau terselip.

2. Pengelolaan Surat Keluar 
Pengelolaan surat keluar di Kantor Badan Pertanahan Nasional (BPN) Kabupaten Klaten yaitu membuat konsep surat terlebih dahulu, hasil konsep surat diserahkan kepada Kepala Seksi masing-masing disertai dengan buku pengantar surat untuk dapat diperiksa, apabila sudah benar maka surat diketik oleh pegawai dan dimintakan nomor surat serta tanggal surat ke Bagian Tata Usaha dengan disertasi melakukan pencatatan pada buku agenda surat keluar. Kemudian surat tersebut dimintakan tanda tangan kepada Kepala Seksi atau Kepala Kantor, setelah itu dicap atau stempel oleh pegawai, selanjutnya Bagian Tata Usaha meminta satu salinan surat keluar tersebut untuk dapat diarsipkan. Surat keluar yang telah selesai dibuat kemudian dimasukkan ke dalam amplop untuk dapat dikirim ke alamat surat tersebut.

Proses pengelolaan surat keluar tersebut sesuai dengan pernyataan Ig. Wursanto (2007: 111) bahwa langkah-langkah yang harus dilakukan dalam mengelola surat keluar adalah menerima dikte atau konsep tertulis dari pimpinan, membuat konsep surat, mencatat pada buku register keluar, mengetik surat dalam bentuk akhir, meminta tanda tangan pimpinan, mengecek surat yang akan dikirim, mendistribusikan surat.

\section{Penataan dan Penyimpanan Arsip Dinamis}

Berdasarkan hasil penelitian yang telah dilakukan di Kantor Badan Pertanahan Nasional (BPN) Kabupaten Klaten, mengenai penataan dan penyimpanan arsip dapat dilakukan pembahasan sebagai berikut:

1. Pelaksanaan Penataan dan Penyimpanan Arsip Dinamis

Arsip yang telah selesai diproses kemudian disimpan pada masing-masing tempat penyimpanan arsip. Arsip umum seperti surat, dokumen keuangan, dokumen perencanaan, dan lain sebagainya disimpan pada box file yang dilengkapi dengan folder, sedangkan arsip yang berhubungan dengan dokumen pendaftaran tanah seperti arsip buku tanah, arsip gambar ukur dan surat ukur, serta arsip warkah di tempatkan pada rak, mobile file, filling cabinet, dan almari.

Proses penataan dan penyimpanan arsip tersebut sesuai dengan pernyataan Basir Barthos (2013: 255) mengenai prosedur yang harus dilakukan sebelum surat disimpan dalam box file yaitu surat yang telah diteliti, disortir disiapkan dalam bak segera dipindahkan masuk ke dalam folder (map) yang bersangkutan (sesuai dengan kodenya). Cara memasukkan ke dalam folder sebagai berikut:

a. Muka surat menghadap ke depan folder

b. Kepala surat harus disebelah kiri 

c. Penyimpanan menurut tanggal (yang terbaru berada di depan)
d. Arsip jawaban surat dijepitkan pada surat yang bersangkutan.

2. Sistem Penyimpanan Arsip

Sistem penyimpanan arsip yang digunakan adalah sistem nomor, sistem wilayah, dan sistem tanggal. Sistem penyimpanan tersebut disesuaikan dengan aturan pada masing-masing ruang penyimpanan arsip. Mengenai sistem nomor menggunakan nomor hak milik, sistem wilayah menggunakan kecamatan atau desa, dan sistem tanggal menggunakan tahun saja. Tidak ada aturan yang baku dalam pemilihan sistem penyimpanan arsip. Pegawai yang mengurusi arsip diberikan keleluasan dalam pemilihan sistem penyimpananan. Catatan pentingnya, pemilihan sistem penyimpanan mampu memudahkan pegawai dalam menyimpan dan menemukan kembali arsip yang diperlukan. Asas penyimpanan arsip menggunakan asas campuran, yaitu sentralisasi dan desentralisasi. Pengelolaan arsip aktif dilakukan secara desentralisasi di setiap Seksi, sedangkan pengelolaan arsip inaktif dilakukan secara sentralisasi di Bagian Tata Usaha. Perihal asas penyimpanan arsip dinamis tersebut sesuai dengan pernyataan Agus Sugiarto dan Teguh Wahyono (2005: 22) bahwa “...pengelolaan arsip aktif dilakukan secara desentralisasi dan arsip inaktif secara sentralisasi. Prakteknya banyak organisasi yang menggunakan sistem pengorganisasian kombinasi ini”.

3. Perlengkapan Penyimpanan Arsip

Perlengkapan penyimpanan arsip yang digunakan di kantor BPN Klaten yaitu ordner dan box file (kotak arsip) dengan dilengkapi folder yang digunakan di setiap Seksi dan Subbagian, kemudian perlengkapan penyimpanan arsip pada masing-masing ruang arsip dokumen pendaftaran tanah meliputi album, spidol warna putih, spidol warna hitam, stapler untuk menyatukan file, sampul arsip (folder), perforator (pelubang kertas), kertas karton, benang, dan lem. Perlengkapan tersebut digunakan untuk memudahkan dalam penyimpanan arsip dan bermanfaat sebagai pelindung dari kerusakan maupun kehilangan pada arsip. Perihal perlengkapan penyimpanan arsip dinamis tersebut telah sesuai pernyataan Agus Sugiarto dan Teguh Wahyono (2005: 79) bahwa perlengkapan penyimpanan arsip yaitu map (folder) dan penyekat (karton). Perlu dilakukan penyegaran dan pembaruan peralatan penyimpanan kerasipan di kantor BPN Klaten mengingat arsip-arsip di kantor tersebut merupakan arsip yang mempunyai nilai tinggi di masyarakat.

4. Peralatan Penyimpanan Arsip 
Peralatan penyimpanan arsip yang digunakan seperti di ruang arsip buku tanah menggunakan mobile file, filling cabinet, dan almari besi. Kemudian peralatan pada ruang arsip gambar ukur dan surat ukur, serta ruang arsip warkah menggunakan rak arsip besi dan rak arsip kayu. Kondisi semua peralatan cukup baik, namun peralatan tidak cukup untuk menampung semua arsip, hanya peralatan pada ruang arsip gambar ukur dan surat ukur yang masih dapat menampung arsip. Perlu penampanan perlatan penyimpanan arsip agar semua arsip tertata dengan rapi. Perihal penyimpanan arsip di kantor BPN Klaten sudah sesuai dengan dengan teori pertimbangan dalam memilih perlengkapan penyimpanan menurut Badri Munir Sukoco (2007: 99) sebagai berikut:

a. Jenis dokumen yang akan disimpan

b. Kecepatan pemanfaatan yang diperlukan

c. Kebutuhan ruangan

d. Pertimbangan keamanan

e. Biaya peralatan

f. Biaya operasional penyimpanan

g. Jumlah pemakai yang mengakses dokumen secara teratu

5. Ruangan dan Kondisi Lingkungan Penyimpanan Arsip

Mengenai ruangan penyimpanan arsip bahwa pada setiap seksi dan Subbagian yang menangani arsip umum belum memiliki ruangan khusus untuk menyimpan arsip, sehingga hanya menjadikan ruangan kerja untuk menyimpan arsip yang bersifat umum. Arsip yang berhubungan dengan dokumen pendaftaran tanah seperti arsip buku tanah, gambar ukur dan surat ukur, serta warkah telah memiliki ruang arsip masing-masing, ketiga ruangan tersebut kondisinya terawat hanya saja tidak begitu luas untuk menampung arsip. Kemudian dinding ruangan belum terbuat dari bahan tahan api serta belum terbebas dari gangguan rayap, tikus, dan serangga.

Mengenai kondisi lingkungan penyimpanan arsip juga harus mendapat perhatian dari para pegawai agar arsip yang telah disimpan dapat terjaga kondisi arsip dan keamanannya. Sesuai dengan hasil observasi yang telah dilakukan di Kantor Badan Pertanahan Nasional (BPN) Kabupaten Klaten bahwa cahaya yang masuk ke dalam ruangan sudah cukup baik karena sinar matahari tidak langsung mengenai arsip yang disimpan. Pencahayaan diperoleh dari cahaya matahari dan cahaya lampu yang menyala setiap jam kerja di setiap ruangan penyimpanan arsip. Keadaan temperatur udara dalam ruangan sudah baik berkisar antara $23^{\circ} \mathrm{C}$ sampai dengan $25^{\circ} \mathrm{C}$, warna ruangan sudah cukup baik yaitu warna Cream (tidak terlalu cerah dan tidak terlalu gelap) sehingga tidak 
mengganggu kerja pegawai. Kondisi lingkungan penyimpanan arsip kurang terawat seperti rak dan almari arsip masih berdebu yang mengakibatkan kerusakan pada sebagian arsip yang tidak disimpan dalam album. Melihat kondisi tersebut, sebaiknya kantor BPN membuat jadwal pemeliharaan arsip secara rutin.

Dari tiga ruang penyimpan arsip di kantor BPN, hanya ada satu AC (Air Conditioner) di ruang arsip buku tanah yang masih hidup, sedangkan di ruang arsip gambar ukur dan surat ukur terpasang AC (Air Conditioner) namun kondisinya sudah mati serta di ruang arsip warkah memang belum tersedia. Keberadaan AC (Air Conditioner) berpengaruh terhadap arsip-arsip yang disimpan, seperti pernyataan Basir Barthos (2013: 56) bahwa “...perlulah pula memasang AC, yang dipasang selama 24 jam terus-menerus. AC ini selain berfungsi untuk mengatur kelembaban dan temperatur udara juga untuk mengurangi banyaknya debu...”. Kantor BPN perlu memperbaiki AC yang rusak dan menyiapkan alat pengukur temperatur udara dan kelembaban udara (thermohigrometer).

\section{Peminjaman dan Penemuan Kembali Arsip Dinamis}

Peminjaman arsip dilakukan sewaktu ada pegawai yang berkepentingan maupun Kepala Seksi yang hendak meminjam arsip. Peminjam arsip harus mencatat terlebih dahulu di buku pinjam arsip atau buku bon arsip. Arsip yang berupa dokumen pendaftaran tanah sifatnya penting sehingga hanya pegawai tertentu yang dapat meminjam, bahkan pihak eksternal sama sekali tidak boleh meminjam. Jangka waktu peminjaman arsip tidak ditentukan lamanya, sehingga apabila kepentingan dalam meminjam sudah selesai, maka harus segera dikembalikan. Perihal tersebut sesuai dengan pernyataan Dorotul Yatimah (2009: 209) bahwa peminjam arsip diharuskan mengisi daftar peminjam arsip. Setiap pegawai yang memerlukan arsip harus mencatat pada buku pinjam arsip. Bagian yang perlu diperhatikan adalah durasi peminjaman arsip. Kantor BPN Klaten sebaiknya mempunyai aturan tentang durasi peminjaman arsip. Durasi peminjaman arsip dapat ditentukan berdasarkan jenis dan sifat arsip yang akan dipinjam.

Proses penemuan kembali arsip di Kantor Badan Pertanahan Nasional (BPN) bahwa terlebih dahulu petugas arsip melihat dan menanyakan arsip apa yang ingin ditemukan, selanjutnya petugas mencari arsip tersebut pada album atau pada jilidan yang terdapat pada tempat penyimpanan arsip (mobile file, filling cabinet, almari arsip, maupun rak arsip). Kemudian apabila arsip tersebut tidak ditemukan, tindakan yang dilakukan petugas arsip dengan mencari pada buku pinjam arsip untuk mengetahui dan menemui pegawai 
sebelumnya yang melakukan peminjaman arsip. Kondisi tersebut sesuai dengan pernyataan Dewi Anggrawati (2005: 23) yang mengemukakan bahwa tata cara penemuan kembali arsip yaitu apabila permintaan itu langsung dari tata usaha pengolah yang bersangkutan, maka petugas tata usaha pengolah dengan kode dan masalah yang sudah diketahui mencari melalui label laci filing kabinet, guide, dan foldernya. Lebih cepat lagi bila indeks arsip diketahui, tinggal mencari folder dengan tab yang mencantumkan indeks tersebut.

Durasi waktu yang diperlukan untuk menemukan kembali arsip membutuhkan waktu lebih dari satu menit, yaitu sekitar 2 (dua) sampai dengan 5 (lima) menit. Penyimpanan arsip yang kurang disiplin menjadi kendala saat penemuan kembali arsip. Secara garis besar penemuan kembali arsip di Kantor Badan Pertanahan Nasional (BPN) Kabupaten Klaten belum dapat dikatakan baik, karena waktu penemuan kembali arsip lebih dari 1 (satu) menit. Agar permasalahan ini dapat diselesaikan, kantor BPN Klaten sebaiknya harus segera memulai pengelolaan arsip secara baik. Salah satu cara yang dapat dilakukan yaitu mengirimkan pegawai yang mengurusi arsip untuk mengikuti pelatihan tentang kearsipan.

\section{Pemeliharaan dan Pengamanan Arsip Dinamis}

Pemeliharaan arsip di Kantor BPN Kabupaten Klaten menunjukkan bahwa pemeliharaan arsip belum dilaksanakan dengan baik. Pemeliharaan arsip hanya dilakukan oleh petugas arsip di ruang arsip gambar ukur dan surat ukur dengan melakukan pembersihan album dari debu menggunakan kemoceng setiap seminggu sekali, sedangkan ruang arsip buku tanah dan ruang arsip warkah kurang begitu diperhatikan. Pemeliharaan pada ruang arsip warkah dilakukan dengan cara memberi kapur barus untuk mengusir serangga.

Pengamanan arsip dinamis di Kantor BPN Kabupaten Klaten sudah cukup baik dengan adanya CCTV. Pengamanan arsip dilakukan langsung oleh semua pegawai, tetapi yang bertanggung jawab secara langsung mengenai keamanan arsip adalah petugas arsip pada masing-masing ruang penyimpanan arsip. Arsip yang berhubungan dengan dokumen pendaftaran tanah sifatnya sangat penting, sehingga hanya pegawai tertentu yang dapat meminjam dan melihat arsip tersebut, sedangkan pihak eksternal tidak diperbolehkan untuk meminjam arsip tersebut. Kegiatan pengamanan arsip juga dilakukan dengan selalu menutup pintu dan mengunci pintu ruang penyimpanan arsip ketika jam kerja telah selesai. Perihal tersebut sesuai dengan pernyataan Agus Sugiarto dan Teguh Wahyono (2005: 92) bahwa usaha pengamanan arsip yaitu petugas arsip harus betul-betul orang yang dapat menyimpan rahasia, harus dilakukan pengendalian dalam peminjaman arsip, diberlakukan larangan bagi 
semua orang selain petugas arsip mengambil arsip dari tempatnya, dan arsip diletakkan pada tempat yang aman dari pencurian.

\section{KESIMPULAN}

Berdasarkan hasil penelitian dan pembahasan yang telah diuraikan, maka dapat disimpulkan sebagai berikut:

1. Pengelolaan Arsip Dinamis di Kan Kantor Badan Pertanahan Nasional (BPN) Kabupaten Klaten mencakup:

a. Pengelolaan surat masuk dilakukan di Bagian Tata Usaha, sedangkan pengelolaan surat keluar pada proses pembuatannya dilakukan di masing-masing seksi. Pengelolaan surat keluar di Kantor Badan Pertanahan Nasional (BPN) Kabupaten Klaten belum dilaksanakan dengan tepat karena masih mengalami keterlambatan pembalasan surat.

b. Pelaksanaan penataan dan penyimpanan arsip dilakukan setelah arsip dilakukan pemrosesan. Kemudian untuk menjaga kondisi arsip agar tidak rusak sehingga perlu diletakkan pada album arsip atau jilidan arsip. Selanjutnya album dan jilidan arsip tersebut disimpan dalam mobile file atau rak sesuai dengan jenis dan klasifikasi arsip.

c. Pelaksanaan peminjaman arsip dilakukan ketika pegawai maupun Kepala Seksi hendak meminjam arsip, dengan terlebih dahulu mencatat pada buku pinjam arsip. Buku pinjam arsip ini digunakan sebagai bukti bahwa arsip telah dipinjam.

d. Pelaksanaan penemuan kembali arsip dilakukan ketika ada pegawai yang hendak meminjam arsip. Penemuan kembali arsip membutuhkan waktu yang cukup lama yaitu dua menit sampai dengan lima menit.

e. Pelaksanaan pemeliharaan arsip hanya dilakukan di salah satu ruang penyimpanan arsip dengan cara membersihkan arsip dari debu menggunakan kemoceng.

f. Pelaksanaan pengamanan arsip dilakukan dengan cara memberikan izin hanya kepada pegawai yang berkepentingan untuk dapat melihat dan meminjam arsip. Ruang penyimpanan arsip juga ditutup dan dikunci. Ruang arsip buku tanah juga dilengkapi CCTV yang terpasang di depan pintu masuk.

\section{DAFTAR PUSTAKA}


Agus Sugiarto dan Teguh Wahyono. (2005). Manajemen Kearsipan Modern. Yogyakarta: Gaya Media.

Badri Munir Sukoco. (2007). Manajemen Administrasi Perkantoran Modern. Jakarta: Erlangga.

Basir Barthos. (2013). Manajemen Kearsipan. Jakarta: PT Bumi Aksara.

Dewi Anggrawati. (2005). Membuat dan Menjaga Sistem Kearsipan. Bandung: Armico.

Dorotul Yatimah. (2009). Kesekretarisan Modern dan Administrasi Perkantoran. Bandung: Pustaka Setia.

Ida Nuraida. (2012). Manajemen Administrasi Perkantoran. Yogyakarta: Kanisius.

Kurniatun. (2011). "Peran Pengelolaan Arsip Kartografi dalam Menunjang Layanan Informasi di Arsip UGM”. Jurnal Kearsipan (Nomor 1). Hlm 142.

Sutirman. (2010). Inovasi Pembelajaran Kearsipan Digital di Era Industri. Makalah disajikan dalam Orasi Ilmiah Dies Natalis ke-7 Fakultas Ekonomi, di Universitas Negeri Yogyakarta.

The Liang Gie. (2009). Administrasi Perkantoran Modern. Yogyakarta: Liberty.

Undang-Undang Nomor 43 Tahun 2009.

Wursanto, Ig. (2007). Kearsipan 2. Yogyakarta: Kanisius.

\section{PROFIL SINGKAT}

Pasha Pradipta Putri, lahir di Sukoharjo pada tanggal 7 Januari 1997 dan merupakan mahasiswi program studi Pendidikan Administrasi Perkantoran Fakultas Ekonomi Universitas Negeri Yogyakarta angkatan 2015.

Purwanto, M.M., M.Pd., merupakan dosen program studi Pendidikan Administrasi Perkantoran. Lahir pada tanggal 3 April 1957. Menempuh pendidikan S1 Pendidikan Administrasi di IKIP Yogyakarta lulus pada tahun 1982, S2 Manajemen di IPWI Jakarta lulus pada tahun 1996, dan S2 PTK di Universitas Negeri Yogyakarta lulus pada tahun 2010.

Wahyu Rusdiyanto, M.M., merupakan dosen program studi Pendidikan Administrasi Perkantoran. Lahir pada tanggal 11 Agustus 1991. Menempuh pendidikan S1 Pendidikan Administrasi di UNY dan lulus pada tahun 2013. Menempuh pendidikan S2 Manajemen di UNS dan lulus pada tahun 2016. 